\title{
Free amino acid profile of Bubalus bubalis L. meat from the Campania region
}

\author{
Nicola Landi', Antonella M. A. Di Giuseppe1, Sara Ragucci' ${ }^{1}$, Antimo Di Maro \\ ${ }^{1}$ Second University of Naples, Department of Environmental, Biological and Pharmaceutical Sciences and Technologies, Caserta, Italy.
}

\begin{abstract}
In this study, we determined the amount of carnosine and anserine in water buffalo meat without hanging treatment and the free amino acid profile by using amino acid analyser with post-column ninhydrin derivatization procedure. The main free amino acids present in samples were glutamic acid ( $>60 \mathrm{mg} / 100 \mathrm{~g})$, followed by alanine, glycine, and arginine. Other protein amino acids were detected in minor amounts (less than $2 \mathrm{mg} / 100 \mathrm{~g}$ ). Among the non-protein amine-containing compounds, taurine and urea were the most abundant. The analysis showed that $50 \%$ of the total free amino acids was represented by dipeptides carnosine (average $\sim 130.3 \mathrm{mg} / 100 \mathrm{~g}$ ) and anserine (average $\sim 17.9 \mathrm{mg} / 100 \mathrm{~g}$ ). Thus, this study for the first time reports the free amino acids profile of water buffalo meat and the content of carnosine and anserine, potentially involved in the darkening meat process and their ratio, that could be used to estimate the water buffalo meat portion in mixed meat products.
\end{abstract}

Key Words: anserine, carnosine, free amino acids, meat analysis, water buffalo

\section{Introduction}

Water buffalo (Bubalus bubalis L.), a large-ruminant animal, plays an important role in human nutrition (Borghese, 2011), as a source of milk and raw meat. The breeding expansion of this species in the world has been encouraged because of its ability to adapt to various climatic conditions, greater digestibility of poor quality pasture, and faster growth, making it a versatile and useful species for sustainable livestock production (Naveena and Kiran, 2014).

Meat produced by buffaloes has gained increased popularity in Africa and several south-eastern and middleeastern Asian countries. In terms of composition, quality, and organoleptic characteristics, water buffalo meat is almost similar to cattle meat (beef), while at the same time appreciated for lower fat, cholesterol, and calories (Infascelli et al., 2003). Based on these properties, the nutritional quality of buffalo meat can be considered of great interest, also for the possibility of development of value-added meat products. Furthermore, water buffalo is very well known thanks to its milk used for the production of "mozzarella", a typical Italian cheese renowned worldwide (European Commission, 1998), providing a valuable source of economic development for this region.

Received November 20, 2015 and accepted July 6, 2016.

Corresponding author: antimo.dimaro@unina2.it

http://dx.doi.org/10.1590/S1806-92902016001000008

Copyright (C) 2016 Sociedade Brasileira de Zootecnia. This is an Open Access article distributed under the terms of the Creative Commons Attribution License (http://creativecommons.org/licenses/by/4.0/), which permits unrestricted use, distribution, and reproduction in any medium, provided the original work is properly cited.
In this scenario, in Italy, the continued milk demand for mozzarella production has extensively increased water buffalo breeding, whereas only recently have Italian stockbreeders strived to also make attractive buffalo meat, derived from male animals, as an alternative to the bovine one. A problem encountered by Italian consumers is the brown colour of buffalo meat compared with beef. Indeed, the colour of fresh meat is an important property that influences its market value and the purchase decision of the consumer (Liu et al., 1996; Mancini and Hunt, 2005). Many researchers report that the meat colour depends on diet of animals, glycogen storage, chilling rate, or antioxidant accumulation (Castellano et al., 2009), all of which can relate to physicochemical parameters such as $\mathrm{pH}$, oxygen consumption, and metmyoglobin reducing activity (Suman and Joseph, 2013; Dosi et al., 2006; Giaretta et al., 2013). Moreover, several studies have indicated a possible correlation between meat colour and carnosine and anserine content in livestock meats. Carnosine and anserine are the most abundant compounds in the non-protein nitrogen fraction of vertebrate muscle tissue (Martignoni and Winnick, 1954). The function of these dipeptides is not clearly defined; nevertheless, these molecules possess strong and specific antioxidant properties (Quinn et al., 1992), and buffering activity during physical exercise (Suzuki et al., 2006; Culbertson et al., 2010). At the same time, studies about meat have found that natural antioxidants, such as carnosine and anserine, influence the meat colour, though the mechanism by which in particular carnosine inhibits the formation of metmyoglobin from myoglobin is unclear (Kohen et al., 1988). 
In this study, we report data on the free amino acid content of water buffalo meat after quick extraction in ethanol followed by sulfosalicylic acid precipitation from three different Campania abattoirs without meat hanging treatment. The free amino acid content extracted was determined by cation exchange liquid chromatography and post-column ninhydrin derivatization. Also the contents of carnosine and anserine dipeptides were determined using the same procedure.

\section{Material and Methods}

Sulfosalicylic acid, ethanol and standard amino acids were from Sigma-Aldrich (Milan, Italy). All chemicals and solvents for the automated amino acid analysis were obtained from Biochrom (Cambridge, UK). The internal standard (nor-leucine) was purchased from Mann Research Laboratory (New York City, NY, USA). Carlo Erba Reagents (Milan, Italy) provided chemicals and solvents for the Kjeldahl method.

The meat samples (longissimus dorsi muscle) from male buffalo animals (ages between 15 and 16 months) without hanging treatment analysed for the characterization of water buffalo (B. bubalis) were collected from three different Campania (Southern Italy) abattoirs. The muscle was quickly withdrawn from the butchered animal and, then, each sample was powdered with porcelain mortar and pestle (i.d. $130 \mathrm{~mm}, 320 \mathrm{~mL}$ ) in liquid $\mathrm{N}_{2}$, until particles of homogeneous size were obtained. Samples were then transferred to $50 \mathrm{~mL}$ polypropylene bottles (Falcon, Becton Drive, Franklin Lakes, NJ, USA), covered with silver paper and stored at $-80^{\circ} \mathrm{C}$ until use (Devine et al., 1996).

To calculate the total protein content: nitrogen concentration was obtained by using the Kjeldahl method (AOAC_976.05, 2000), and the total protein content was estimated using a nitrogen factor of 6.25. Samples (about $1.0 \mathrm{~g})$ were analysed using a Mineral Six digester and an Auto Disteam semi-automatic distilling unit (VWR International PBI, Milam, Italy). For the total lipid content, sample aliquots $(5.0 \mathrm{~g})$ were lyophilized using a FTSSystem Flex-Dry ${ }^{\mathrm{TM}}$ instrument (SP Scientific, Stone Ridge, NY USA). The materials, extracted by the Soxhlet apparatus with $\mathrm{CHCl}_{3}$ for $4 \mathrm{~h}$, were dried using a rotary evaporator to obtain the lipid extracts, which were weighed giving the amount of extracted fat. To obtain the water content, a sample $(2.0 \mathrm{~g})$ was dried in a thermostatically controlled oven at temperatures of $98-100^{\circ} \mathrm{C}$ until the constant weight was obtained (AOAC 953.07, 2000).

For the analysis of free amino acids, aliquots of frozen powdered meat samples $(100 \mathrm{mg})$ were precipitated with
$80 \%$ cold ethanol $(1.0 \mathrm{~mL})$, in the presence of nor-leucine $(50 \mathrm{nmol})$ as internal standard, homogenized with a Teflon ${ }^{\circledR}$ pestle, and centrifuged at about $14000 \mathrm{~g}$, at $4{ }^{\circ} \mathrm{C}$ (Iriti et al., 2009). The supernatant was lyophilized, treated with $3 \%$ sulfosalicylic acid $(500 \mu \mathrm{L})$ to precipitate any protein fraction still present, and centrifuged again (Di Maro et al., 2011). A suitable amount of sample (generally 6.25 or $25 \mu \mathrm{L}$ ) of this extract was directly analysed. Each sample was individually prepared and analysed in triplicate.

A Biochrom30 (Cambridge, UK) amino acid analyser, equipped with a polyvinyl sulfonate cationic-exchange column for physiological fluids, a post-column ninhydrin derivatization system, and a two-channel detection system set at 570 and $440 \mathrm{~nm}$ (the second for proline and hydroxyproline) was used, adapting the Stein and Moore procedure (Stein and Moore, 1963).

Analyses were repeated three times for each sample; the mean and standard deviation (SD) of experimental values are reported. The results were analysed statistically by employing the computer program GraphPad Prism version 5.0 (GraphPad Software, Inc., La Jolla, CA-USA). Data were subjected to statistic Tukey's HSD test to calculate the significance $(\mathrm{P}<0.05)$.

\section{Results and Discussion}

Moisture, protein, and lipid values of water buffalo from Campania region were similar to those reported in previously works. In particular, our results (Table 1) showed that the protein content $(21.13 \mathrm{~g} / 100 \mathrm{~g})$ of water buffalo meat is similar to the $20.50 \mathrm{~g} / 100 \mathrm{~g}$ reported by Fonseca et al. (2005) and the $20.39 \mathrm{~g} / 100 \mathrm{~g}$ reported by USDA Food Composition Database (USDA, 2016), while they were slightly lower than the $23.43 \mathrm{~g} / 100 \mathrm{~g}$ reported by Rey and Povea (2012). The lipid content $(1.69 \mathrm{~g} / 100 \mathrm{~g})$ is higher than the $0.52 \mathrm{~g} / 100 \mathrm{~g}$ reported by Rey and Povea (2012), but similar to the 1.75 reported by Fonseca et al. (2005) the $1.37 \mathrm{~g} / 100 \mathrm{~g}$ reported by USDA Food Composition Database (USDA, 2016). Finally, moisture $(74.23 \mathrm{~g} / 100 \mathrm{~g})$ was similar to the $74.26 \%$ reported by Rey and Povea (2012).

Table 1 - Moisture, protein, and lipid values of the longissimus dorsi muscle of male buffaloes

\begin{tabular}{lccc}
\hline L. dorsi muscle & Moisture & Proteins & Lipids \\
\hline Abattoir 1 & $76.3 \pm 3.81 \mathrm{a}$ & $21.3 \pm 1.07 \mathrm{a}$ & $1.40 \pm 0.07 \mathrm{a}$ \\
Abattoir 2 & $73.9 \pm 3.70 \mathrm{a}$ & $22.1 \pm 1.11 \mathrm{a}$ & $1.60 \pm 0.06 \mathrm{a}$ \\
Abattoir 3 & $72.5 \pm 3.63 \mathrm{a}$ & $20.0 \pm 1.00 \mathrm{a}$ & $2.07 \pm 0.08 \mathrm{~b}$ \\
Overall mean & 74.23 & 21.13 & 1.69
\end{tabular}

Results are expressed as g per $100 \mathrm{~g}$ on a fresh weight basis.

Values are means ( \pm standard deviation) of triplicate analyses $(n=3)$.

Results followed by different letters in the column are significantly different, according to Tukey's HSD $(\mathrm{P}<0.05)$. 
However, the data confirm that water buffalo meat has great advantages over beef for human consumption because of its protein content and lower fat content (Infascelli et al., 2003), while in beef meat raw protein and lipid contents are on average 19.23 and $10.93 \mathrm{~g} / 100 \mathrm{~g}$, respectively (USDA, 2016).

Comparing the free amino acid contents among the three abattoirs operating in Campania, no qualitative differences were observed, whereas quantitative differences were found. The total free amino acid contents for $100 \mathrm{~g}$ meat in abattoir-1, abattoir-2, and abattoir-3 were 155.79, 171.35 , and $181.78 \mathrm{mg}$, respectively (Table 2).

Glutamic acid was by far the most abundant among the free amino acids (about 40.90, 34.66, and $45.76 \%$ for abattoir-1, abattoir-2, and abattoir-3, respectively). The alanine content was also quite abundant in the three different samples. Among the free amino acids, glycine, arginine, and asparagine were highly present, in descending order
( $\geq 2 \mathrm{mg}$ for $100 \mathrm{~g}$ ). All samples showed the presence of nonprotein amino acids. Their total amounts in abattoir-1, abattoir-2, and abattoir-3 were $3.36,5.01$, and $4.83 \mathrm{mg} / 100 \mathrm{~g}$, respectively. Moreover, ethanolamine, $\beta$-alanine, and ornithine were the most abundant compounds obtained from the three different abattoirs. The amounts of essential amino acids (histidine, isoleucine, leucine, lysine, methionine, phenylalanine, threonine, valine, and tryptophan) in abattoir-1, abattoir-2, and abattoir-3 were 9.27, 10.36 and $8.52 \mathrm{mg} / 100 \mathrm{~g}$, respectively.

Finally, taurine (2-aminoethanesulfonic acid) and urea contents in the three different samples were highly present, with $17.9 \%$ and $14.8 \%$ of the total, respectively.

However, despite these slight differences in amino acid amount among the sampled meat from abattoir-1, abattoir-2, and abattoir-3, the content of free amino acids in water buffalo meat without hanging treatment was substantially the same (Tables 1 and 2).

Table 2 - Free amino acid content of water buffalo meat samples without hanging treatment from Campania region abattoirs

\begin{tabular}{|c|c|c|c|c|}
\hline Amino acid & Abattoir 1 & Abattoir 2 & Abattoir 3 & Overall mean \\
\hline \multicolumn{5}{|l|}{ Essential amino acids } \\
\hline L-histidine ${ }^{1}$ & $0.86 \pm 0.17 \mathrm{a}$ & $0.78 \pm 0.05 a$ & $0.71 \pm 0.05 \mathrm{a}$ & 0.78 \\
\hline L-isoleucine $^{1}$ & $1.63 \pm 0.11 \mathrm{a}$ & $1.76 \pm 0.18 \mathrm{a}$ & $1.44 \pm 0.13 \mathrm{a}$ & 1.61 \\
\hline L-leucine $^{1}$ & $2.04 \pm 0.20 \mathrm{a}$ & $1.94 \pm 0.39 \mathrm{a}$ & $1.60 \pm 0.11 \mathrm{a}$ & 1.86 \\
\hline L-lysine $^{1}$ & $1.25 \pm 0.11 \mathrm{a}$ & $1.56 \pm 0.31 \mathrm{a}$ & $1.32 \pm 0.26 \mathrm{a}$ & 1.37 \\
\hline L-methionine ${ }^{1}$ & $0.22 \pm 0.02 \mathrm{a}$ & $0.29 \pm 0.06 \mathrm{a}$ & $0.21 \pm 0.03 \mathrm{a}$ & 0.24 \\
\hline L-phenylalanine ${ }^{1}$ & $0.61 \pm 0.12 \mathrm{a}$ & $0.68 \pm 0.07 \mathrm{a}$ & $0.33 \pm 0.04 \mathrm{a}$ & 0.54 \\
\hline L-threonine ${ }^{1}$ & $0.95 \pm 0.08 \mathrm{a}$ & $1.32 \pm 0.14 \mathrm{a}$ & $1.13 \pm 0.08 \mathrm{a}$ & 1.13 \\
\hline L-tryptophan ${ }^{1}$ & nd & nd & nd & - \\
\hline L-valine $^{1}$ & $1.71 \pm 0.14 \mathrm{a}$ & $2.03 \pm 0.22 \mathrm{a}$ & $1.78 \pm 0.18 \mathrm{a}$ & 1.84 \\
\hline \multicolumn{5}{|l|}{ Non-essential amino acids } \\
\hline L- $\alpha$-aminoadipic acid & nd & nd & nd & - \\
\hline L-alanine $^{1}$ & $19.57 \pm 3.52 \mathrm{a}$ & $21.79 \pm 1.96 \mathrm{a}$ & $19.92 \pm 3.98 \mathrm{a}$ & 20.42 \\
\hline L-arginine $^{1}$ & $1.89 \pm 0.28 \mathrm{a}$ & $2.63 \pm 0.53 \mathrm{a}$ & $2.32 \pm 0.23 \mathrm{a}$ & 2.28 \\
\hline L-asparagine $^{1}$ & $1.47 \pm 0.27 \mathrm{a}$ & $2.68 \pm 0.54 \mathrm{a}$ & $1.83 \pm 0.20 \mathrm{a}$ & $1.99 \mathrm{a}$ \\
\hline L-aspartic acid ${ }^{1}$ & $1.72 \pm 0.24 \mathrm{a}$ & $2.34 \pm 0.23 \mathrm{a}$ & $1.83 \pm 0.16 \mathrm{a}$ & 1.96 \\
\hline$\beta$-alanine & $0.71 \pm 0.11 \mathrm{a}$ & $1.48 \pm 0.10 \mathrm{~b}$ & $1.21 \pm 0.12 \mathrm{ab}$ & 1.14 \\
\hline L-citrulline & nd & $0.48 \pm 0.03 \mathrm{a}$ & $0.52 \pm 0.05 \mathrm{a}$ & - \\
\hline L-half cystine ${ }^{1}$ & nd & nd & nd & - \\
\hline Ethanolamine & $1.63 \pm 0.18 \mathrm{a}$ & $2.17 \pm 0.32 \mathrm{a}$ & $1.75 \pm 0.17 \mathrm{a}$ & 1.85 \\
\hline$\gamma$-aminobutirric acid & nd & nd & nd & - \\
\hline Glycine $^{1}$ & $3.51 \pm 0.53 \mathrm{a}$ & $4.46 \pm 0.71 \mathrm{a}$ & $3.86 \pm 0.39 \mathrm{a}$ & 3.94 \\
\hline L-glutamine $^{1}$ & $1.53 \pm 0.32 \mathrm{a}$ & $1.35 \pm 0.12 \mathrm{a}$ & $1.21 \pm 0.18 \mathrm{a}$ & 1.37 \\
\hline L-glutamic acid ${ }^{1}$ & $63.73 \pm 3.11 \mathrm{a}$ & $59.39 \pm 4.16 \mathrm{ab}$ & $83.18 \pm 4.64 \mathrm{ac}$ & 68.76 \\
\hline L-ornithine & $0.57 \pm 0.08 \mathrm{a}$ & $1.32 \pm 0.09 \mathrm{~b}$ & $1.10 \pm 0.04 b$ & 0.99 \\
\hline O-phosphoethanolamine & nd & nd & $0.11 \pm 0.01$ & - \\
\hline O-phospho-L-serine & $0.15 \pm 0.01$ & nd & nd & - \\
\hline L-proline ${ }^{1}$ & $0.49 \pm 0.08 \mathrm{a}$ & $1.43 \pm 0.07 \mathrm{~b}$ & $1.11 \pm 0.18 \mathrm{ab}$ & 1.01 \\
\hline L-sarcosine & $0.30 \pm 0.03 \mathrm{a}$ & $0.32 \pm 0.03 \mathrm{a}$ & $0.32 \pm 0.03 \mathrm{a}$ & 0.32 \\
\hline L-serine $^{1}$ & $1.69 \pm 0.10 \mathrm{a}$ & $2.47 \pm 0.37 \mathrm{a}$ & $2.12 \pm 0.21 \mathrm{a}$ & 2.10 \\
\hline Taurine & $33.43 \pm 3.01 \mathrm{a}$ & $26.58 \pm 2.25 \mathrm{a}$ & $23.87 \pm 2.39 \mathrm{a}$ & 27.96 \\
\hline L-tyrosine ${ }^{1}$ & $0.45 \pm 0.05 \mathrm{a}$ & $0.80 \pm 0.07 \mathrm{~b}$ & $0.61 \pm 0.04 \mathrm{ab}$ & 0.62 \\
\hline Urea & $13.67 \pm 2.19 \mathrm{a}$ & $29.30 \pm 2.05 b$ & $26.38 \pm 1.22 b$ & 23.12 \\
\hline Total (mg) & 155.79 & 171.35 & 181.78 & $(156.31)$ \\
\hline
\end{tabular}

Results are expressed as milligrams of amino acids per $100 \mathrm{~g}$ of sample.

nd - not detected.

Results followed by different letters in the row are significantly different, according to Tukey's HSD test $(\mathrm{P}<0.05)$.

Values are means $( \pm$ standard deviation) of triplicate analyses $(n=3)$ and are expressed on weight basis.

${ }^{1}$ Protein amino acids. 
By using a Biochrorm30 amino acid analyser physiological system, simultaneously to the free amino acid profile, it is possible to determine the content of some dipeptides such as carnosine ( $\beta$-alanyl-L-histidine) and anserine ( $\beta$-alanyl-N-methylhistidine). The total amounts of carnosine in abattoir-1, abattoir-2, and abattoir-3 were $124.73,139.20$, and $126.84 \mathrm{mg} / 100 \mathrm{~g}$, respectively, whereas the content of anserine was $25.59,14.22$ and $13.79 \mathrm{mg} / 100 \mathrm{~g}$, respectively (Figure 1). These data showed that the water buffalo meat contains more carnosine and less anserine, such as reported for beef and pork meats (Aristoy and Toldrà, 2004). In particular, all these values are lower than those reported for the $l$. dorsi beef muscle as previously reported (Mateescu et al., 2012; Toldrà and Reig, 2012), typically 372 and $66 \mathrm{mg} / 100 \mathrm{~g}$ of muscle for carnosine and anserine, respectively. Furthermore, the content of carnosine (average $\sim 130.3 \mathrm{mg} / 100 \mathrm{~g}$ ) and anserine (average $\sim 17.9 \mathrm{mg} / 100 \mathrm{~g}$ ) represents $50 \%$ of the total free amino acids, with a ratio of 7.3 fold higher for carnosine compared with anserine. The ratio obtained for the first time related to water buffalo meat without hanging treatment is interesting because it is specific to each species and could be used to identify products made from water buffalo meat as previously reported for other species (Huang and Kuo, 2000; Tinbergen and Slump, 1976).

Finally, these analyses show that water buffalo meat is a source of carnosine, a natural anti-aging constituent of the human body (dose for anti-aging benefits 100 to $200 \mathrm{mg}$ /die (Gariballa and Sinclair, 2000)).

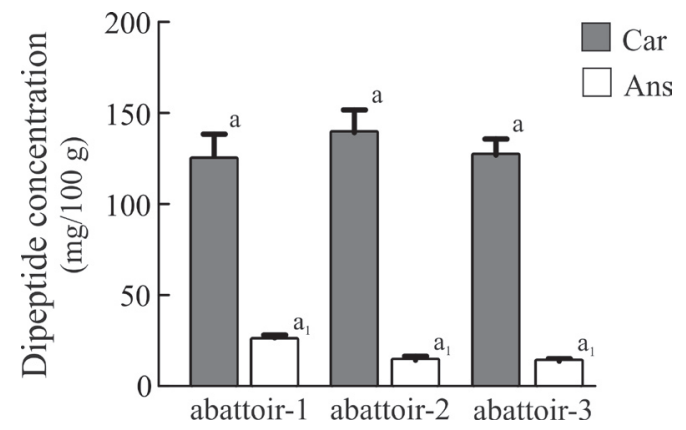

Car - carnosine; Ans - anserine

Values are means ( \pm standard deviation) of triplicate analyses $(n=3)$.

Results followed by same letter are not significantly different, according to Tukey's HSD test $(\mathrm{P}<0.05)$.

Figure 1 - Carnosine and anserine content of water buffalo meat from three different Campania abattoirs.

\section{Conclusions}

The carnosine and anserine contents in water buffalo meat are lower than those in beef, and thus there may be a possible correlation between the contents of these dipeptides and the faster darkening process of water buffalo meat, likely together with other physiological factors (e.g., myoglobin content, lipid peroxidation).

However, despite the lower content of carnosine, our study suggests that the water buffalo meat gives a good intake of this substance, an advantage to its known natural anti-aging capacity.

\section{Acknowledgments}

This study is the result of the dedication of all the participants, despite the absence of dedicated funds and chronic difficulties affecting the Italian scientific community. On the other hand, we thank the MIUR-Italy (PON03PE_00060_2 (PON 2007-2013)).

\section{References}

AOAC 953.07. 2000. AOAC Official method 953.07. p.4. In: Official methods of analysis of AOAC International. v.1. 17th ed. Horwitz, W., ed. AOAC International, Gaithersburg, MD, USA.

AOAC 976.05. 2000. AOAC Official method 976.05. p.23. In: Official methods of analysis of AOAC International. v.1. 17th ed. Horwitz, W., ed. AOAC International, Gaithersburg, MD, USA.

Aristoy, M. C. and Toldrà, F. 2004. A simple, fast and reliable methodology for the analysis of histidine dipeptides as markers of presence of animal origin proteins in feed for ruminants. Food Chemistry 84:485-491.

Borghese, A. 2011. Situation and perspectives of buffalo in the World, Europe and Macedonia. Macedonian Journal of Animal Science 1:201-296.

Castellano, I.; Cecere, F.; De Vendittis, A.; Cotugno, R.; Chambery, A.; Di Maro, A.; Michniewicz, A.; Parlato, G.; Masullo, M.; Avvedimento, E. V.; De Vendittis, E. and Ruocco, M. R. 2009. Rat mitochondrial manganese superoxide dismutase: amino acid positions involved in covalent modifications, activity, and heat stability. Biopolymers 91:1215-1226.

Culbertson, J. Y.; Kreider, R. B.; Greenwood, M. and Cooke, M. 2010. Effects of beta-alanine on muscle carnosine and exercise performance: A review of the current literature. Nutrients 2:75-98.

Devine, C. E.; Bell, R. G. and Lovatt, S. 1996. Reads meats. p.51-84. In: Freezing effects on food quality. Jeremiah, L. E., ed. Marcel Dekker, New York, USA.

Di Maro, A.; Dosi, R.; Ferrara, L.; Rocco, M.; Sepe, J.; Ferrari, G. and Parente, A. 2011. Free amino acid profile of Malus domestica Borkh cv. Annurca from the Campania Region and other Italian vegetables. Australian Journal of Crop Science 5:154-161.

Dosi, R.; Di Maro, A.; Chambery, A.; Colonna, G.; Costantini, S.; Geraci, G. and Parente, A. 2006. Characterization and kinetics studies of water buffalo (Bubalus bubalis) myoglobin. Comparative Biochemistry and Physiology - Part B: Biochemistry \& Molecular Biology 145:230-238. 
European Commission, C. R. 1998. № 2527/98. Official Journal of the European Communities 41:L 317/314-318.

Fonseca, D. M.; Prado, I. N.; Visentainer, J. V.; Matsushita, M. and de Souza, N. E. 2005. Longissimus dorsi chemical composition and fatty acid profile in Murrah. Buffalo (Bubalus bubalis) heifers fattened in drylot with hormonal implantation and lead spheres in the uterus. Journal of Animal and Veterinary Advances 4:462-466.

Gariballa, S. E. and Sinclair, A. J. 2000. Carnosine: physiological properties and therapeutic potential. Age and Ageing 29:207-210.

Giaretta, N.; Di Giuseppe, A. M.; Lippert, M.; Parente, A. and Di Maro, A. 2013. Myoglobin as marker in meat adulteration: a UPLC method for determining the presence of pork meat in raw beef burger. Food Chemistry 141:1814-1820.

Huang, S. C. and Kuo, J. C. 2000. Concentrations and antioxidative activity of anserine and carnosine in poultry meat extracts treated with demineralization and papain. Proceedings of the National Science Council, Republic of China Part B, Life Sciences 24:193-201.

Infascelli, F.; Cutrignelli, M. I.; Bovera, F.; Piccolo, G.; Tudisco, R.; Calabrò, S.; Zicarelli, F. and Piccolo, V. 2003. Nutritional characteristics of buffalo meat: Cholesterol content and fatty acid composition. Bubalus Bubalis 4:51-57.

Iriti, M.; Di Maro, A.; Bernasconi, S.; Burlini, N.; Simonetti, P.; Picchi, V.; Panigada, C.; Gerosa, G.; Parente, A. and Faoro, F. 2009. Nutritional traits of bean (Phaseolus vulgaris) seeds from plants chronically exposed to ozone pollution. Journal of Agricultural and Food Chemistry 57:201-208.

Kohen, R.; Yamamoto, Y.; Cundy, K. C. and Ames, B. N. 1988. Antioxidant activity of carnosine, homocarnosine, and anserine present in muscle and brain. Proc. Natl. Acad. Sci. USA 85:3175-3179.

Liu, Q.; Scheller, K. K.; Arp, S. C.; Schaefer, D. M. and Williams, S. N. 1996. Titration of fresh meat color stability and malondialdehyde development with Holstein steers fed vitamin E-supplemented diets. Journal of Animal Science 74:117-126.

Mancini, R. A. and Hunt, M. C. 2005. Current research in meat color. Meat Science 71:100-121.
Martignoni, P. and Winnick, T. 1954. Biosynthesis of carnosine and anserine in the chick. Journal of Biological Chemistry 208:251-261.

Mateescu, R. G.; Garmyn, A. J.; O’Neil, M. A.; Tait, R. G., Jr.; Abuzaid, A.; Mayes, M. S.; Garrick, D. J.; Van Eenennaam, A. L.; VanOverbeke, D. L.; Hilton, G. G.; Beitz, D. C. and Reecy, J. M. 2012. Genetic parameters for carnitine, creatine, creatinine, carnosine, and anserine concentration in longissimus muscle and their association with palatability traits in Angus cattle. Journal of Animal Science 90:4248-4255.

Naveena, B. M. and Kiran, M. 2014. Buffalo meat quality, composition, and processing characteristics: Contribution to the global economy and nutritional security. Animal Frontiers 4:18-24.

Quinn, P. J.; Boldyrev, A. A. and Formazuyk, V. E. 1992. Carnosine: its properties, functions and potential therapeutic applications. Molecular Aspects of Medicine 13:379-444.

Rey, J. F. and Povea, I. E. 2012. Water Buffalo (Bubalus bubalis) and their technological advantages for the design in healthy meat product. Journal of Buffalo Science 1:183-187.

Stein, W. H. and Moore, S. 1963. Chomatographic determination of amino acids by the use of automatic recording equipment. Methods in Enzymology 6:819-831.

Suman, S. P. and Joseph, P. 2013. Myoglobin chemistry and meat color. Annual Review of Food Science and Technology 4:79-99.

Suzuki, Y.; Nakao, T.; Maemura, H.; Sato, M.; Kamahara, K.; Morimatsu, F. and Takamatsu, K. 2006. Carnosine and anserine ingestion enhances contribution of nonbicarbonate buffering. Medicine and Science in Sports and Exercise 38:334-338.

Tinbergen, B. J. and Slump, P. 1976. The detection of chicken meat in meat products by means of the anserine/carnosine ratio. Zeitschrift fur Lebensmittel-Untersuchung und -Forschung 161:7-11.

Toldrà, F. and Reig, M. 2012. Biochemystry of raw meat and poultry. p.287-302. In: Food biochemistry and food processing. 2nd ed. Simpson, B. K., ed. Wiley \& Sons, Iowa, USA.

USDA Food Composition Database, Release 28 2016. USDA National Nutrient Database for Standard Reference. Available at: $<$ http://ndb.nal.usda.gov/>. Accessed on: Sept. 9, 2016. 